\title{
The Research about the Methods to Construct Exquisite Course on "the History of China's Ancient Finance"
}

\author{
Cao Lin \\ (Institute of Public Finance and Taxation, Hebei University of Economics and Business, \\ shijiazhuang 050061, China)
}

Keywords: the history of China's ancient finance; exquisite course; educational reform

\begin{abstract}
The construction of exquisite courses is one of the very important projects in universities. As far as finance is concerned, the complementary relationship about learning professional historiography and professional knowledge are very worth paying attention to. Therefore, exquisite course construction on "the history of China's ancient finance" has its importance and necessity. This article analyzes mainly from the teaching content, teachers team, teaching methods and means, and practical contents etc, in order to introduce the construction conception of this course, and through which this article want to discuss the way to construct professional historiography exquisite courses.
\end{abstract}

"Any social system will be produced only with the finance of a certain class support." It is the material basis that country's fiscal levy supports and maintains the emergence, consolidation and development of social system in each historical period. National finance and tax have a long history, and their reform and development have profoundly influenced the evolution of social system for thousands of years. It has been reflecting the shift of various dynasties in Chinese history. As a result, It is helpful to the observation and understanding of the practical problems that students combine the basic theory, knowledge and methods of finance and taxation , understand and grasp its basic evolution, characters and regulation of the history of Chinese ancient finance. It can also provide some useful experience for reference for our country's ongoing fiscal and taxation system reform. Therefore, we believe that the complementary relationship about learning professional historiography and professional knowledge are very worth paying attention to. Thus, on the basis of this knowledge, working on construction of "the history of Chinese ancient finance" exquisite courses is more worth our in-depth studying and exploring.

\section{The Construction Of Teaching Content}

The quality of the construction of the teaching content is the key to the construction of exquisite courses, and its core is to solve the problem of how to design a good course content. In the process of construction of "the history of Chinese ancient finance" exquisite courses, generally speaking, we need to start from several aspects:

(a) Teaching content must conform to the teaching purpose

Currently, the purpose of quality education in universities, is that trying to make students independently apply some ideas or theories to explain and solve real problems on the basic of students comprehensively understanding the curriculum theories and ideas. So, this requests from a comprehensive perspective to organize the teaching content, help students to grasp the basic knowledge of the courses comprehensively and in-depth. In terms of "the history of China's ancient finance” course, the design of teaching contents will require to know both ancient and modern, carefully select and utilize the relevant historical data, and with important historical events as the clue, to elaborate the basic theory and evolution of fiscal and taxation history, and connect the system evolution with social change. Not only the evolution, characteristics and laws of Chinese taxation system development in thousands of years should be mastered, but also the gain and loss in its evolution of the fiscal and taxation system in China for thousands of years history need to be further understood. Taking history as a mirror, it makes them serve the fiscal and taxation systems 
of socialism with Chinese characteristics in the near future.

(b) The teaching content must meet the needs of students

The design of teaching content, must pay attention to starting from the actual situation of the students. First of all, the students' learning demands should be understood; Second, the basic knowledge structure that students have need to be known approximately; In addition, the cause that students' attention to the curriculum also should be known. Especially based on the reality that there is a widespread awareness "learning history is useless" in current society and the lack of historical education to economy class students, the teaching content design of "the history of China's ancient finance” course should even more start from the needs of students. The design of teaching content must be vivid, detailed and interesting, and maximum limit, maximum depth inspire students' thirst for knowledge. At the same time, the teaching content be simple and accessible as far as possible, not beyond the students understanding ability. It also should abandon the obscure original historical materials, both achieving as detailed as possible and embodying the key points, difficulties and methods of study. It could increase students' attention to the course through teaching content.

(c) The teaching content must be combined with the related courses knowledge

Finance and taxation has its own specialized knowledge system, of which all courses also have their own characteristics. As a compulsory course for students majoring in finance and taxation, the course on "the history of China's ancient finance" has a more intimate connection with other professional main courses such as the "finance and taxation", "taxation", etc. Therefore, we should actively expand relevant knowledge, to make "the history of China's ancient finance" course achieve continuous optimization of teaching content and structure under obeying the arrangement of the whole structure of professional and establish a relatively stable and dynamic updating teaching system. So, we need to lay emphasis on constantly putting the basic theories, knowledge and methods of other professional courses into the study of "the history of China's ancient finance" course. In the process of teaching, it is combined with the historical events to analyze and address specific historical views and opinions. Then, this can make students learn professional historiography knowledge from different angles, at the same time, it also gradually raises the level of students' comprehensive analysis ability and the overall theory. It can form the inner link among the related courses, furthermore, form a complete cognitive system. Thus it boost the whole construction of finance and taxation.

(d) The teaching content must be timely updated

In the teaching process of professional historiography, we must pay attention to the accommodation of history and reality. As American educator, Dewey said, the subject, history, makes the natural science and the humanities, two became one. No matter how the natural science progresses, from the perspective of education, it is a part of the humanities. Therefore, teachers should not only design the teaching content carefully and pay attention to the scientificity, systematicness, applicability of knowledge, but also must pay attention to bring the latest research achievements of this subject and related subjects to the classroom teaching timely, constantly update and improve the teaching content. And, in the process of teaching, while teaching the developing regulation and the main clue of the history of China's ancient finance, explaining and commenting on the important financial events, teachers should also introduce and analyze the hot related academic issues as well, in order to achieve the purpose of one instance. Teachers should guide students to connect the past and present, and make professional historiography really become a knowledge combining history with reality.

\section{The Construction of Teaching Staff}

There is no doubt that a high level of teaching staff is the guarantee of exquisite courses construction. A complete teaching staff includes the course director, the chief course instructor, practice teacher, guidance counselor, etc..Its task is that designing and updating the content of exquisite courses, establishing teaching resources, researching teaching methods, constantly improving teaching level and practical ability, then promoting the course to perfect and forming a virtuous interaction. The construction of teaching staff, must start from the long-term planning and 
project step by step, and establish an effective incentive mechanism.

(a)The mechanism of cultivation

The construction of excellent teaching staff of exquisite courses must require a good training mechanism. There are various methods of cultivation, the most common and effective way is "the old with the new". On the one hand, it can take advantage of existing resources, on the other side, can also enhance the feelings between teachers. Of Course, we can also adopt other methods. For instance, pushing young teachers to study to other universities at home and abroad, employing experts both inside and outside universiyies to engage in special training, etc.

(b) The mechanism of competition

An effective competitive mechanism may stimulate the potential. It is similarly important to the construction of teachers' team. Currently, the ever-present problems in the professional historiography education are that the style and the content of the lecturer are often a few years or even more than ten years not updated, and the lack of awareness updating and method innovation. But the adoption of the competitive mechanism, can fundamentally change the bad situation.

(c) The mechanism of external employment

The external staff is usually more prominent scholars in this field. The main purpose of the external mechanism is learning from each other in mutual emulation and introducing advanced teaching ideas or effective teaching methods. It should be noted that the external mechanism conforms to the actual situation of the courses and the direction of course construction and development. At the same time, the external mechanism requires long-term planning, in order to form a necessary complement to their own teaching resources, and then close to or reach the goal of course construction.

So to speak, the main body of the construction of exquisite courses is teachers, so you must adequately attach importance to the construction of teaching staff. Building up a teaching staff having reasonable structure, stable staff, high teaching level, teaching teaching effect good, can guarantee the quality of teaching, and then become exquisite courses.

In addition, the teaching and scientific research are a dialectical and unified entirety. In theprocess of the construction of exquisite courses teaching staff, the combination of teaching and scientific research still should be emphasizd. The so-called "title" out of teaching, scientific research doing the "article", teaching benefits teachers as well as students, and to promote each other. Therefore, in the teaching process, teachers need to pay attention to the research direction, and form the research results and then apply to the teaching... So, through the teaching extracting scientific research topic, can constantly improve teachers' scientific research level. More importantly, this research results from teaching, finally can serve the teaching directly, and improve teaching quality. "The high levels of course depends on a high level of academic support, teacher's scientific research and teaching is unified on this point."

\section{The Construction of Teaching Methods and Means}

Classroom is a site where teaching target, teaching ability, teaching art are synthetically reflected, and it is the main channel to promote all development of students, such as knowledge, intelligence, emotion. Similarly, professional historiography courses also bear the responsibility. Therefore, the construction of exquisite course on "the history of China's ancient finance", not only should have the perfect teaching content, excellent teachers, but also possess the good teaching methods and means. Only in this way, can we mobilize the enthusiasm and initiative of student learning. Especially, economic class students usually exist misunderstanding to professional historiography that think it boring, and the teaching means that laundry list or rustle name are more unattractive for them. So teaching methods and means need to be improved and perfected.

(a) Taking appropriate teaching methods

First of all, the basic teaching method is still a teacher to teach professional historiography.But in the process of teaching the "the history of China's ancient finance" course, teachersmust be good at presenting the abundant historical facts clearly and vividly to students, andpay attention to avoid listing the historical materials and telling in a simple, straightforwardway. They should try their best 
to teaching concisely, vulgarly and popularly. In addition,they can design some historical events plotling, extract some theories from the history, and show the history vividly in front of the students with vivid and interesting language. It can make them find that history is not a boring things and willing to accept.

Second, the professional historiography education also should pay attention to the classroom interaction. The process of teaching, should be regarded as the active process of communication, improving together between teachers and students. Therefore, in the classroom teaching, to fully improve the students' participation, teachers can put forward some controversial problems and points around historical events, and let the students discuss in groups and exchange opinions. So, it can stimulate the ability the student thinking actively, further be more beneficial to the deep understanding of what they learned. Of course, after students elaborating their views, teachers need to express personal opinions and introduce the academic mainstream view. Finally, teachers need to summarize them and make the students obtain a comprehensive understanding of these problems.

Mr. Cai Yuanpei once said that "educators, advocate its nature, rather than keep the methods; and show personality, rather than pursuit its consistent." No matter adopt what kind of teaching methods, its purpose is to arouse interest, active thinking, and cultivate students' ability of independent thinking and analysis.

(b) Making use of abundant teaching means

First of all, with the diversity of students' requirements for classroom teaching, to improve the quality of classroom teaching, teachers need to actively use modern teaching means such as multimedia in teaching. The course "the history of China's ancient finance" itself contains a large number of historical figures and historical events. Compared with other courses in finance and taxation, it is more suitable for multimedia teaching which broadcasts the related historical pictures and video data. It can fully mobilize students' senses, make the history of the "death" knowledge "live", and help the students to circulate cultural relics pictures and in-kind. Then, it make students gain more intuitive sense, and make the student's understanding of history from abstract to concrete.

In the making of multimedia courseware, in order to attract students' interest in learning, the best way is to reproduce history, to enhance the intuition and figurativeness of classroom teaching. At present, with network technology developing, the web sites ,such as the Chinese Civilization Network, the Chinese Literature and History Network, Chinese Cultural Heritage Network, around the museum sites, are all showing pictures of text certificates, historical relics, historic sites which left over by historyin each historical period. Meanwhile, issued documentary information related to science and education, such as the "Five Thousand Years of Chinese Civilization" "Chinese Historiette", "Archaeological China" and "World History", should be able to become the source of "the history of China's ancient finance" multimedia teaching materials, it makes the Chinese ancient history of the fiscal and taxation vividly be reappeared to class. So, the classroom teaching can comprehensively apply figures, texts and objects. So that the students' understanding of the history is from abstract to specific, simple and clear image. It also makes teaching content more rich, and greatly increases the amount of information.Such it not only can change the boring and single teaching atmosphere in the professional historiography class, broaden the students' horizon, and eliminate their sense of distance for the professional historiography, but also make the students feel about professional history from a tasteless to relish, improve their participation consciousness, and optimize teaching effect well.

Second, the construction of network curriculum should be strengthened. It is the biggest characteristic of exquisite courses that providing the specification, intuitive, and convenient learning resources. And the network is the best platform. Generally speaking, the content of the course teaching platform should be very complete. For instance, it can provide teaching plans and outline downloaded easily, and electronic lesson plans suitable for multimedia, to facilitate students self-study; Also it should be able to offer teachers teaching cases, to facilitate student self-test; And, due to the characteristics of the course of "the history of China's ancient finance", namely, it exists a large number of intuitive historical materials. So online course can directly provide photos, video and other materials that teachers choose or related website links effectively. At the same time, you 
can also set the column of online communication that can be convenient for communication between teachers and students.

\section{The Construction of practice Content}

In terms of exquisite courses' construction, the importance of the construction of practice content is as the teaching content. The teaching of "the history of China's ancient finance" course, as well as, needs to strengthen the interaction of theory and practice. Famous educator Bacon claims: "the study of learning, not like ants who are very diligently accumulated unvaluable data, also not like spiders who can only weave a seamless web but is empty. The best way is like the bees. Bees gather nectar selectively outside, go through their own internal digestion and manufacturing, eventually make the sweet honey."

To design the practice contents of professional historiography courses, firstly we need to grasp the knowledge which can be combined with practice in the course. You can have reference value for some important tax historical issues, request students to go to the reference room and library to look up the relevant data. For example, when teaching the differences of Chinese and western feudal tax system, teachers could require students to issue "comparing Chinese and western feudal tax thoughts", to write articles or reports. In the process of data collecting and article writing, students not only need to know about the professional knowledge of history, but also collect and analyse historical data, and then independently think to solve the problem. There is no doubt that it can cultivate students' scientific research level and improve their practice ability. At the same time, besides the papers and reports, we can take the form of students' academic salon to discuss the professional historiography issues. To make the question more targeted, teachers may establish the discussed basis point, arguments, and rough contextin advance, then let students free play and discuss. In this way, not only it can make discussed problems concentrated and ordered, but also encourage students to speak freely. In addition, academic exchange interactions between teachers and students also can be appropriately increased. Such as making full use of the panel and network, or leading students to attend the related subjects, to broaden their horizons.

Aim at the present condition that taxation students historical knowledge is relatively poor, we can purposefully strengthen the training. Some specific measures can be took as following:

(1) Combined with the content of the professional historiography courses, students are required to read history books, relevant historical materials, etc., and make well reading notes.

(2) Before the knowledge of every chapter taught, present research situation and the important content of the relevant information in this chapter should be introduced fristly, and the bibliography should be listed.

(3) Combined with the key difficulties of each chapter, students should be guided to complete 1 or 2 small papers or reports each semester.

(4) 2-3 class hours should be drought out and used to class discussion or organizing academic salon each semester.

(5) Utilizing the network system, we can open up the column of professional historiography courses teaching and discussion, encourage students to ask questions that teachers will answer, and builds the platform for the communication between teachers and students to discuss.

Anyhow, the exquisite courses construction is a system engineering and a process which is needed for a long time and constantly improved. Especially given the current economic class professional students attitude towards professional historiography a generally ignored, and the characters of the professional historiography courses, we must set out actually, construct a reasonable mechanism, and make a detailed practical plan to achieve the desired purpose. At the same time, only professional historiography teachers diligently explore, constantly enrich themselves, and broaden the knowledge structure, theoretical depth and the amount of information, can they constantly improve the level and quality of teaching, enhance the teaching effect, meet the new needs of modern education, at last establish the real practical value of exquisite courses. 


\section{References}

[1] Zhou Guanglin, Liu Chunsheng, Xu Wenjuan. The practice and thinking about exquisite courses construction[J]. Journal of Heilongjiang College of Education,2011（01）

[2] Wang Hongbo, Hou Xilin. The thinking about "Economics" provincial exquisite courses construction[J]. China Adult Education, 2007 (05)

[3] Wang Yuewang. Discuss the construction on "Ancient history of the world" exquisite courses [J]. Journal of LangFang Teachers College（Social Sciences Edition）, 2009（04）

[4] Sun Rongxia. The summary of exquisite courses construction[J]. Heilongjiang Science and Technology Information, 2007 (02)

[5] Zhao Pei. Introduction to the construction of exquisite courses[J]. Journal of Urumqi Vocational, $2008(02)$ 